International Research Journal of Management, IT \& Social Sciences
Available online at https://sloap.org/journals/index.php/irjmis/
Vol. 7 No. 1, January 2020, pages: 205-216
ISSN: 2395-7492
https://doi.org/10.21744/irjmis.v7n1.837

\title{
Auditors Experience as Moderating Effect Investigative Abilities and Understanding of Red Flags on Fraud Detection
}

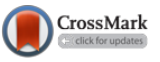

Anak Agung Surya Narayana ${ }^{a}$

Dodik Ariyanto $^{b}$

\section{Article history:}

Submitted: 27 November 2019

Revised: 09 December 2019

Accepted: 13 January 2020

\section{Keywords:}

auditor's experience;

fraud detection;

investigative abilities;

moderating;

red flags;

\begin{abstract}
This study was aimed to examine the auditor's experience as moderating to the effect of investigative abilities and understanding of red flags on fraud detection. There are several factors that affect the detection of fraud is the investigative ability and red flags. But these factors have an inconsistent effect, and it is suspected that this is moderated by the auditor's experience. This research was conducted at the state development audit agency (BPKP) province of Bali in 2019. The number of samples taken was 83 auditors who were willing to participate in this study. The sample in the study was determined by purposive sampling method. The data analysis technique used is Partial Least Square (PLS) analysis. Based on the results of the study it was found that higher investigative abilities make better the detection of fraud. The higher red flags, make better the fraud detection. The higher of auditor's experience, make better the fraud detection. The more experienced of the auditor, can be stronger the effect of investigative abilities on fraud detection. The auditor's experience is not able to moderate the effect of understanding of red flags on fraud detection, with R-square value (R2) of $82.3 \%$.
\end{abstract}

International research journal of management, IT and social sciences (C) 2020. This is an open access article under the CC BY-NC-ND license (https://creativecommons.org/licenses/by-nc-nd/4.0/).

\section{Corresponding author:}

Anak Agung Surya Narayana,

Faculty of Economic and Business of Udayana University, Denpasar, Indonesia.

Email address: surya_gung@icloud.com

Udayana University, Denpasar, Indonesia

${ }^{\mathrm{b}}$ Udayana University, Denpasar, Indonesia 


\section{Introduction}

Detection of fraud is an attempt to get sufficient initial indications of fraud, while at the same time narrowing the space for the perpetrators of fraud (Salem, 2012). Activities to detect fraud, auditors usually start by identifying indicators that are indicative of possible fraud (Zimbelman et al., 2014). Fraud detection does not always get a bright spot because of the underlying motivations, and the many methods of cheating (Kassem \& Higson, 2012). Attribution theory developed by Fritz Heider in 1958 basically wanted to explain the causes of one's behavior, in this case, the auditor's inability to detect fraud. In the context of audits, attribution theory is widely used by researchers to explain auditor behavior, performance appraisal, and decision making by auditors. Behavior is caused by internal strength or by external forces (Walgito, 2002). Auditors in detecting fraud a lot are determined by internal strength, where the factors that determine more come from the auditor's ability itself (Kartikarini, 2016). While external forces in this study are red flags (Suartana, 2010).

An auditor who performs fraud detection tasks is required to have skills and skills, especially in the field of forensics and investigation (Tuanakotta, 2012). So that the auditor must have the ability to detect fraud. One of the internal strengths is the ability to apply the knowledge that is owned, in conducting audit procedures, so that it can carry out audits carefully, carefully, intuitively and objectively. Investigative ability is an internal auditor factor that must be possessed by an investigating auditor to find indications of fraud that allows finding evidence of fraud (Rahmawati, 2017). Effective fraud detection in addition to requiring internal strength also requires external forces specifically answering questions about social perception which are also related to self-perception (Kelley, 1973). An auditor's selfperception plays an important role in concluding whether red flags lead to symptoms of fraud or just an error. So that the understanding of the red flags is needed by the auditors to reveal the symptoms of fraud that occur around him (Fullerton \& Durtschi, 2004). Red flags are a strange condition or different from normal conditions or indications of fraud in a financial report (Grabosky \& Duffield, 2001).

Based on previous research, there are still inconsistencies in the results of previous studies. So researchers are interested in reexamining the relationship between investigative ability and understanding of red flags on the detection of fraud by using moderation variables. This moderation variable was identified from Knapp \& Knapp (2001), research that presents the auditor's experience as a quasi-moderator variable, with the results of the study showing that experience can improve the risk assessment associated with the fraud. Attribution theory indicates that effective audit results can be influenced by internal strengths, especially the auditor's experience. Work experience is seen as an important factor in predicting auditor performance (Januarti, 2011). Research by Nair \& Kamalanabhan (2010) explains that the auditor's experience is able to moderate the relationship between a person's attitude and behavior on performance in the area of business management and auditing. Based on this background, the researchers are interested in testing the auditor's experience to moderate the influence of investigative abilities and understanding of red flags on fraud detection.

\section{Literature review and hypotheses development Fraud detection}

Fraud is an act of deception, cunning, and other dishonest ways, which are made by a person or entity and can result in some unfavorable benefits to individuals or entities or other parties (Guelpa et al., 2017). Basically, fraud detection must be used and carried out continuously, because fraud continues to evolve. Ways that can be used to detect fraud include looking at signs, signals, or red flags (Kurniawan, 2018). Understanding of Red flags is an odd condition or different from normal conditions or an indication of fraud in a financial statement (Grabosky \& Duffield, 2001). Research conducted by Hegazy \& Kassem (2010); Moyes et al. (2013); Sanjaya Adi Putra \& Dwirandra (2019); and Prasetyo (2015), find that red flags have a positive effect on fraud detection. However, it is different from Mustika (2016), the research found that there is no relationship between red flags and fraud detection.

\section{Investigative ability}

Investigative ability is an internal auditor factor that must be possessed by an investigative auditor to find indications of fraud that might allow evidence of fraud to be found (Rahmawati, 2017). Gbegi \& Adebisi (2014), explained that investigative ability is the ability to gather facts from various witnesses in a fair, impartial, valid manner (following the statutory provisions) and accurately and be able to report the facts collected in full. Research conducted by Mustika (2016); Lameng \& Dwirandra (2018); Afiani (2019) and Benedikta (2019), the results show that investigative ability 
has a positive effect on the detection of fraud. However, the study of Jaffar et al. (2011); Wijayanti (2014); Dewi \& Ramantha (2019); and Bullah (2017), found that investigative ability had no significant effect on the detection of fraud

Understanding of red flags

Ways that can be used to detect fraud include looking at signs, signals, or red flags (Kurniawan, 2018). Red flags are an odd condition or different from normal conditions or an indication of fraud in a financial statement (Grabosky \& Duffield, 2001). Research conducted by Hegazy \& Kassem, (2010); Moyes et al. (2013); Kustinah (2018) and Pratama (2019), find that red flags have a positive effect on fraud detection. However, it is different from Mustika (2016), the research found that there is no relationship between red flags and fraud detection.

\section{Auditor's experience}

Work experience is seen as an important factor in predicting auditor performance (Januarti, 2011). The auditor will integrate his audit experience with the knowledge he already has. Experienced auditors have more knowledge and better memory structure than less experienced auditors (Widyastuti, 2009). Research by Rahmawati (2017); Andriyanti (2019) and Larasati \& Puspitasari (2019), found a positive relationship between audit experience and fraud detection. Research Nair \& Kamalanabhan (2010), explains that the auditor's experience is able to moderate the relationship between a person's attitude and behavior on performance in the area of business management and auditing. In addition, research Agoglia et al. (2007), also found that specific experience in the audit task can moderate the effect of fraud risk assessment on the auditor's audit ability.

\section{Hypotheses development \\ Effect of investigative ability on fraud detection}

The auditor identifies fraud indicators requiring investigation. An audit to detect the presence or absence of fraud is called an investigative audit (Durkin, 2011). So that auditors are expected to have investigative abilities to detect fraud (Dewi, 2016). Investigative ability is the ability to collect facts from various witnesses fairly, impartially, legitimately (following statutory provisions) and accurate and able to report facts collected in full (Gbegi \& Adebisi, 2014). Dewi (2016), found that investigative ability has a positive and significant effect on the effectiveness of the implementation of audit procedures in detecting fraud. This significant effect is due to the fact that most auditors who have investigative abilities tend to have more qualified basic, technical, and mental attitude in conducting investigative audits to detect fraud. The results of this study are also supported by research conducted by Lameng \& Dwirandra (2018); Afiani (2019) and Benedikta (2019). Thus, it can be hypothesized as follows:

$H_{1}$ : The higher the investigative ability, the better the detection of fraud.

\section{Effect of understanding of red flags on fraud detection}

The auditor when dealing with the red flags when conducting an audit will try to find the cause and make conclusions about the red flags. Red flags are a strange condition or different from normal conditions or indications of fraud in financial statements (Grabosky \& Duffield, 2001). Auditors must be able to analyze these signals carefully, even though the appearance of red flags does not always indicate fraud. So that the self-perception of an auditor plays an important role in concluding whether red flags lead to symptoms of cheating or just an error. A sufficient understanding of the red flags and followed by a good analysis of the irregularities around will help the auditor to find evidence that will indicate the existence of fraud (Prasetyo \& Darmayanti, 2015). Research conducted by Hegazy \& Kassem, (2010); Moyes et al. (2013); Kustinah (2018); and Pratama (2019), found that red flags had a positive effect on the auditor's ability to detect fraud. The higher the understanding of red flags found by auditors, the more effective it will be in detecting fraud. So, it can be hypothesized as follows:

$\mathrm{H}_{2}$ : The higher the red flags, the better the detection of fraud.

\section{Effect of auditor's experience on fraud detection}

The probability of auditors in detecting fraud is influenced by experience in conducting audits (Setiawan \& Fitriany, 2011). The experience becomes an important indicator of the professional qualifications of an auditor. The auditor's

Narayana, A. A. S., \& Ariyanto, D. (2020). Auditors experience as moderating effect investigative abilities and understanding of red flags on fraud detection. International Research Journal of Management, IT and Social 
experience is the entire learning process that the auditor has passed to improve its quality (Knap, 2001). Research conducted by Rahmawati (2017) and Andriyanti (2019) found a positive relationship between audit experience and fraud detection where auditors who have had a lot of experience will not only have the ability to find unusual errors or fraud in the financial statements but also the auditor can provide a more accurate explanation of the findings compared to auditors who still have little experience. This is because experienced auditors will have more knowledge and better memory structure than inexperienced auditors (Larasati, 2019). So, it can be hypothesized as follows:

$H_{3}$ : The higher the auditor's experience, the better the fraud detection.

\section{Auditor's experience moderates the effect of investigative ability on fraud detection}

An investigative auditor in order to succeed in carrying out his duties must have critical and strategic thinking skills, effective communication both written or oral and investigative abilities. In addition to investigative abilities, Mui (2010), the study found a positive relationship between audit experience and fraud detection where experienced auditors proved to be more capable of selecting relevant or irrelevant information or evidence in making decisions. The auditor's experience in this context means the entire learning process that the auditor has passed to improve its quality (Knap, 2001). Larasati \& Puspitasari (2019); and Andriyanti (2019), found that the more auditor experience can produce a variety of allegations in explaining audit findings so that it will improve its ability to detect fraud. In addition. Experience strengthens the effect of fraud risk assessment on the ability to detect fraud (Kiswanto, 2019). So that the more experienced auditors, the investigative ability of auditors will be better in gathering evidence of competent fraud as a basis for decision making in detecting fraud. Thus, it can be hypothesized as follows:

$H_{4}$ : The more experienced of the auditor, the stronger influence of investigative ability on fraud detection.

\section{Auditor experience moderating the effect of understanding red flags on fraud detection}

Auditors must be able to analyze the signals of red flags that do not always indicate fraud. Heiman-Hoffman et al. (1996); Krambia-Kardis, (2002); and Mustika (2016), found no association of red flags against fraud detection. This is because the red flags that appear have not been enough to represent the truth about the existence of fraud in the organization. So that the understanding of the red flags is needed by the auditors to reveal symptoms of fraud that occur around him (Fullerton \& Durtschi, 2004). Maulana \& Kiswanto (2019), state that auditors who are experienced or not, have differences in terms of finding an item that is not common, but has no difference in terms of finding a common item. In this study, these non-general items can be interpreted as the existence of red flags. Jaffar et al. (2011), states that the high level of experience of auditors will be easier to find the presence of red flags in detecting fraud because the number and types of cases found are more than those of less experienced auditors. So it is assumed that the experience of auditors interacting with the red flags will affect the detection of fraud. So that the more experienced auditors will find more symptoms of red flags in proving the truth or failure of these fraud symptoms that affect the detection of fraud. Thus, it can be hypothesized as follows:

$H_{5}$ : The more experienced the auditor, the stronger the influence of understanding red flags on fraud detection.

\section{Materials and Methods}

\section{Research design, sample, and data collection}

This research is associative causality research that aims to obtain empirical evidence related to the effect of investigative abilities and understanding of red flags on fraud detection with the auditor's experience as a moderating variable. This research was conducted at the Financial and Development Supervisory Agency (BPKP) of the Province of Bali. This BPKP office building is located on Street Kapten Tantular, Denpasar. The time of study is 2019. The population is a generalization area consisting of one object or subject that has certain qualities and characteristics set by the researcher to be studied and conclusions drawn later. The populations in this study were auditors of the BPKP Representative of Bali Province, amounting to 117 people. The sample is part of the number and characteristics of the population. Determination of samples using a purposive sampling technique. Purposive sampling is a sampling technique of data sources with certain considerations. The criteria for determining the sample in this study are:

a) Included in the group of functional auditor positions.

b) Auditors who have worked for more than one year. 
Variables and measures

1) Fraud Detection

The indicator used to measure the construct of fraud detection is using indicators summarized by Yusrianti (2015), adopted from Salem (2012). These indicators as follows:

\begin{tabular}{ll}
\hline No & Indicator \\
\hline 1 & Understanding the internal control system \\
2 & Identify fraud risks \\
3 & Understanding the audit environment \\
4 & Audit methods and procedures \\
5 & Development of audit techniques \\
6 & Identify fraud detection barriers \\
7 & Identification of fraudsters. \\
8 & Ease of access to audit \\
9 & Testing audit evidence \\
\hline
\end{tabular}

2) Investigative Ability

The indicators used to measure the construct of investigative ability are using indicators summarized by Dewi (2016) adopted from Gbegi \& Adebisi (2014). The indicators are as follows:

\begin{tabular}{ll}
\hline No & Indicator \\
\hline 1 & Having accounting and auditing knowledge \\
2 & Knowing internal control techniques. \\
3 & Knowing investigative audit standards and techniques \\
4 & Knowing valid evidence \\
5 & Knowing information and technology issues \\
6 & Knowing legal construction \\
7 & Able to prove the fraud hypothesis \\
8 & Independent \\
9 & Critical \\
\hline
\end{tabular}

3) Understanding of Red Flags

The indicators used to measure the construct of understanding of red flags are indicators summarized by Prasetyo (2015) adopted from Fullerton \& Durtschi (2004). The indicators are as follows:

\begin{tabular}{l|l}
\hline No & Indicator \\
\hline 1 & Disputes within the organization \\
2 & Authoritarian leadership \\
3 & Special relationship \\
4 & The realization of the work program is not in accordance with the initial planning \\
5 & Realization of unrealistic budget absorption \\
6 & Weak authorization system \\
7 & Changes in behavior or lifestyle \\
8 & Ignoring the internal control system \\
9 & Justify the occurrence of differences in transactions \\
10 & There is a history of lawlessness \\
11 & Adjustments to account posts \\
12 & Material transactions \\
13 & The comfort of the workplace environment \\
\hline
\end{tabular}

Narayana, A. A. S., \& Ariyanto, D. (2020). Auditors experience as moderating effect investigative abilities and understanding of red flags on fraud detection. International Research Journal of Management, IT and Social Sciences, 7(1), 205-216. https://doi.org/10.21744/irjmis.v7n1.837 
4) Auditor's experience

The indicators used to measure the construct of auditor experience are indicators summarized by Hussin et al. (2017), adopted from Carpenter (2002). These indicators are as follows:

\begin{tabular}{l|l}
\hline No & Indicator \\
\hline 1 & Duration of auditor work \\
2 & Position of auditor \\
3 & An investigative audit conducted \\
4 & Training that has been followed \\
\hline
\end{tabular}

\section{Results and Discussions}

\subsection{Evaluation of Structural Models}

Testing of the model is done by looking at the value of R-square (R2) which is a test of the goodness of the model (Ghozali and Laten, 2015: 66). The R2 result is 0.815 which means that $81.5 \%$ of the fraud detection variables can be accounted for by the investigative ability variable, the red flag, and the auditor's experience when receiving $18.5 \%$ can be changed by other variables. The structural model is shown in Figure 1.

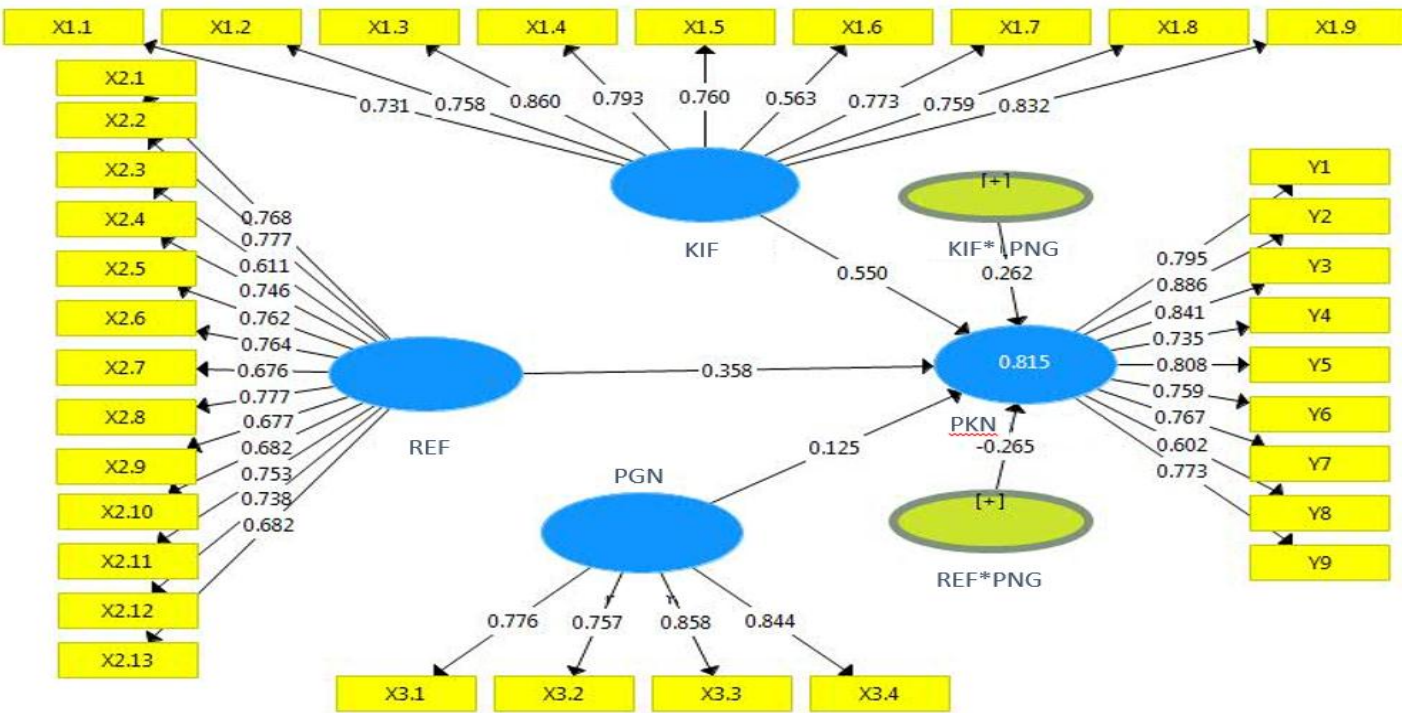

Figure 1. Evaluation of structural models

Where:

PKN $\quad$ : Fraud Detection

KIF $\quad$ : Investigative Ability

REF : Understanding of Red Flags

PNG : : Auditor's Experience

KIF*PNG : Investigative Ability* Auditor's experience

REF*PNG : Understanding of Red Flags* Auditor's experience

\subsection{Hypothesis Testing and Discussions}

Five hypotheses were tested using the Partial Least Square (PLS) approach and the results are presented in Table 1. 
Table 1

Result of hypothesis testing

\begin{tabular}{lllll}
\hline Hypothesis & Original Sample & T-Statistic & P-Values & Result \\
\hline $\mathrm{H}_{1}$ & 0,550 & 4,589 & 0,000 & Significant (Confirmed) \\
$\mathrm{H}_{2}$ & 0,358 & 2,737 & 0,006 & Significant (Confirmed) \\
$\mathrm{H}_{3}$ & 0,125 & 2,180 & 0,030 & Significant (Confirmed) \\
$\mathrm{H}_{4}$ & 0,262 & 2,078 & 0,038 & Significant (Confirmed) \\
$\mathrm{H}_{5}$ & $-0,265$ & 1,960 & 0,051 & Significant (Rejected) \\
\hline
\end{tabular}

According to Table 1, the result is supported by the first hypothesis (H1) because the p-value of 0,000 is smaller than 0.05 . Hence, $\mathrm{H} 1$ has accepted means that the higher the investigative capacity, the better the detection of fraud. Attribution theory developed by Heider in 1958 indicates that to produce an effective audit is determined by internal forces. One of the internal strengths is the ability to apply the knowledge they have in conducting audit procedures so that they can conduct audits carefully, carefully, intuitively and objectively. Investigative ability is the ability to gather facts from various witnesses in a fair, impartial, valid (following the provisions of the legislation) and accurately and be able to report the facts collected in full (Gbegi \& Adebisi, 2014). In accordance with the attribution theory developed by Heider in 1958, it indicates that to produce an effective audit is determined by internal forces. One of the internal strengths is the ability to apply the knowledge they have in conducting audit procedures so that they can conduct audits carefully, carefully, intuitively and objectively. So investigative ability is an internal factor that must be possessed by auditors to find indications of fraud that allows the discovery of evidence of fraud (Rahmawati, 2017). To detect the presence or absence of fraud requires a special audit called an investigative audit (Durkin, 2011). Audit investigations become a basic requirement because the results of the audit are an integral part of the process of proving the existence of indications of fraud (fraud). So the auditor must have the investigative ability to detect fraud (Dickins \& Reisch, 2012). The results of this study are in line with research by Bullah et al. (2017); Lameng \& Dwirandra (2018); Afiani (2019); and Benedikta (2019), who state that the investigative auditor's ability has a positive effect on fraud detection. This is due to the fact that most auditors who have investigative abilities tend to have more qualified basic, technical, and mental attitude in conducting investigative audits to detect fraud.

Based on Table 1 we can find that the result also supports the second hypothesis (H2) because the p-value of 0.006 is smaller than 0.05 . Hence, $\mathrm{H} 2$ is the higher the red flags, the better the detection of fraud. Attribution theory indicates that an effective audit result can be influenced by internal forces, especially the auditor's perception in concluding whether red flags lead to symptoms of fraud or just an error. Red flags are an odd condition or different from normal conditions or an indication of fraud in a financial statement (Grabosky \& Duffield, 2001). In accordance with attribution theory, it indicates that the results of an effective audit can be influenced by internal forces, especially the auditor's understanding in concluding the awkward conditions (red flags) leading to fraud or just being an error. Understanding of red flags is needed by auditors to reveal the symptoms of fraud that occur around them (Fullerton \& Durtschi, 2004). When there are red flags, the auditor will focus more on these strange conditions in order to be able to uncover evidence on the red flags in order to immediately detect possible fraud (Hegazy \& Kassem, 2010). The results of this study are in line with research by Hegazy \& Kassem (2010); Moyes et al. (2013); Kustinah (2018); and Pratama (2019), who found that red flags had a positive effect on fraud detection. When the auditor indicates the existence of red flags, the auditor will be more focused and careful in gathering adequate evidence related to the red flags, so that the impact on the detection of fraud is getting better. A sufficient understanding of red flags and followed by a good analysis of the red flags will help the auditor find evidence that will indicate fraud (Pratama, 2019).

Table 1 also reported strong support for the third hypothesis (H3), because the p-value of 0.030 is smaller than 0.05 . Hence, $\mathrm{H} 3$ is the higher the auditor's experience, the better the detection of fraud. Attribution theory indicates that effective audit results can be influenced by internal strengths, especially the auditor's experience. Work experience is seen as an important factor in predicting auditor performance (Januarti, 2011). Experienced auditors have more knowledge and better memory structure than less experienced auditors (Dasila \& Hajering, 2019). The auditor's experience in this context means the whole learning process that the auditor has passed to improve its quality (Knap, 2001). In accordance with attribution theory, indicating that effective audit results can be influenced by internal forces, especially the experience of auditors. Work experience is seen as an important factor in predicting auditor performance (Januarti, 2011). Auditors with more experience in assignments related to fraud have broader knowledge about fraud. Experience will hone the ability of an auditor, so that more experienced auditors can produce various kinds of allegations of fraudulent behavior that will increase the detection of fraud. This is because experience will shape one's

Narayana, A. A. S., \& Ariyanto, D. (2020). Auditors experience as moderating effect investigative abilities and understanding of red flags on fraud detection. International Research Journal of Management, IT and Social Sciences, 7(1), 205-216. https://doi.org/10.21744/irjmis.v7n1.837 
expertise both technically and psychologically (Rumengan \& Rahayu, 2014). The results of this study are in line with research conducted by Mui (2010); Rahmawati (2017); and Andriyanti (2019), revealed that the audit experience variable has a positive effect on the ability to detect fraud. This is because experienced auditors will have more knowledge and better memory structure than inexperienced auditors. So that experienced auditors have a variety of allegations of fraudulent behavior that have an impact on the detection of fraud more effectively (Larasati, 2019).

Based on Table 1 also reported strong support for the fourth hypothesis (H4), because the p-value of 0.038 is smaller than 0.05 . Hence, $\mathrm{H} 4$ is the stronger the effect of investigative ability on fraud detection. Attribution theory indicates that effective audit results can be influenced by internal strengths, especially the auditor's experience. Work experience is seen as an important factor in predicting auditor performance (Januarti, 2011). The auditor's experience in this context means the whole learning process that the auditor has passed to improve its quality (Knap, 2001). Experienced auditors will have more knowledge and better memory structure than inexperienced auditors. Auditors who have a lot of experience will not only have the ability to find errors (fraud) or fraud (fraud) that is not unusual in the financial statements but the auditor can also provide a more straightforward and accurate explanation (Larasati, 2019). In accordance with attribution theory, indicating the results of an effective audit is influenced by internal forces, especially the experience of auditors. Experience is seen as an important factor in predicting auditor performance (Andriyanti, 2019). Experienced auditors not only have the ability to find errors (fraud) or fraud (fraud) that is not unusual in the financial statements but also can provide a more straightforward and accurate explanation related to these conditions (Benedikta, 2019). An auditor also in carrying out fraud detection is required to have skills and skills, especially in the forensic and investigative fields. Investigative ability focuses on collecting and testing evidence related to fraud that occurred (Afiani, 2019). The results of this study support the research of Agoglia et al. (2007); Mui (2010); and Maulana \& Kiswanto (2019), finding that specific experience in the examination task can moderate the effect of fraud risk assessment on fraud detection. Knapp \& Knapp (2001), also shows that experience can improve the assessment of risks associated with the fraud. This is because the experience of the audit manager has a more effective fraud risk assessment compared to senior auditors.

Based on Table 2 the result did not support the fifth hypothesis (H5) with a p-value of 0.051 greater than 0.05 . Hence, $\mathrm{H} 5$ is rejected, meaning that the auditor's experience is not able to moderate the effect of red flags on fraud detection. This is because as long as the auditor applies audit procedures and professionalism in conducting the audit, the auditor is still able to detect fraud. In addition, this result is also due to the tendency of respondents to lack interaction between auditor experiences with red flags, so the interaction between auditor experiences with red flags has no effect on fraud detection. There may be other variables that have an influence on the detection of fraud but did not become a variable in this study. A reliable auditor should have a lot of audit experience because with so much experience possessed by the auditor will make it easier to find out fraud (Okpianti, 2016). Experienced auditors have differences in terms of finding an item that is not common, but does not have differences in terms of finding an item that is common. In this study, these unusual items can be interpreted as red flags (Jaffar, 2011). The auditor when dealing with red flags when conducting an audit will try to find the cause and make conclusions about the red flags. Jaffar et al. (2011), states that a high level of auditor experience will more easily find the existence of red flags in detecting fraud because the number and type of red flags cases experienced are more than those with less experienced auditors. However, the results of the study indicate that the auditor's experience is not able to moderate the effect of red flags on fraud detection. The results of this study support the research of Fullerton \& Durtschi (2004); Okpianti (2016), who found that the auditor's experience had no significant effect on the auditor's ability to detect fraud. This is because as long as the auditor applies audit standards and professionalism and conducts audit activities in accordance with the ethics of the auditor profession, the auditor is still able to detect fraud.

\section{Conclusion}

The study it was found that higher investigative abilities make better the detection of fraud. The higher the understanding of red flags, the better the detection of fraud. The higher the auditor's experience, make better the fraud detection. The more experienced auditors can be the stronger the effect of investigative abilities on fraud detection. The auditor's experience is not able to moderate the effect of red flags on fraud detection. The results of this study can contribute to the auditor in detecting fraud as follows: to improve investigative capabilities auditors are required to improve understanding of information technology issues related to cases faced and always maintain a mental attitude that is free from outside parties during the investigation so they can be impartial in giving opinions. To increase the sensitivity of red flags auditors to increase attention on individuals who have an authoritarian leadership style in the 
agency being audited and always pay attention to transactions that are material, unusual, or have high complexity in the agency being audited. To increase the experience of auditors so as to increase experience on the assignment of investigative audits and attend training in the area of fraud. To improve fraud detection involves identifying the risk of fraud that requires follow-up to carry out investigations and always paying attention to those who can commit fraud.

\section{Conflict of interest statement}

The authors declared that they have no competing interests.

\section{Statement of authorship}

The authors have a responsibility for the conception and design of the study. The authors have approved the final article.

\section{Acknowledgments}

We are grateful to two anonymous reviewers for their valuable comments on the earlier version of this paper.

Narayana, A. A. S., \& Ariyanto, D. (2020). Auditors experience as moderating effect investigative abilities and understanding of red flags on fraud detection. International Research Journal of Management, IT and Social Sciences, 7(1), 205-216. https://doi.org/10.21744/irjmis.v7n1.837 


\section{References}

Afiani, F. A., Latifah, N., \& Sukanto, E. (2019). Skeptisme Profesional, Pelatihan Audit Kecurangan, Pengalaman Audit dan Kemampuan Auditor dalam Mendeteksi Kecurangan pada Inspektorat Kota dan Kabupaten di Jawa Tengah. In Prosiding Seminar Nasional Mahasiswa Unimus (Vol. 2).

Agoglia, C. P., Brazel, J. F., Hatfield, R. C., \& Jackson, S. B. (2007). The effect of risk of misstatement and workload pressure on the choice of workpaper review format. Available at SSRN 1001469. https://dx.doi.org/10.2139/ssrn.1001469

Andriyanti, D., \& Latrini, M. Y. Pengaruh Pengalaman, Independensi, dan Profesionalisme Auditor Internal Dalam Mencegah Kecurangan Pada Bank Perkreditan Rakyat. E-Jurnal Akuntansi, 475-504. https://doi.org/10.24843/EJA.2019.v27.i01.p18

Benedikta N., Jurjur F., \& Carolina Lenny. (2019). The Influence of the Capability and Experience of the Investigative Forensic Auditor on the Effectiveness of the Implementation of Audit Procedures. Proceedings of the 2nd Expert National Seminar. Page 2341-2347. Trisakti University.

Bullah, H., \& Prasetyono, S. M. (2017). Faktor-Faktor Yang Memengaruhi Kualitas Bukti Audit Investigasi.

Carpenter, M. A. (2002). The implications of strategy and social context for the relationship between top management team heterogeneity and firm performance. Strategic Management Journal, 23(3), 275-284. https://doi.org/10.1002/smj.226

Dasila, R. A., \& Hajering, H. (2019). Pengaruh pengalaman, independensi dan skeptisme profesional auditor terhadap pendeteksian fraud. paradoks: Jurnal Ilmu Ekonomi, 2(1), 61-80.

Dewi, N. P. R. A., \& Ramantha, I. W. (2019). Effect of conflict and unclear role on auditor performance with emotional quotient as moderating variable. International Journal of Social Sciences and Humanities, 3(3), 50-59. https://doi.org/10.29332/ijssh.v3n3.350

Dewi, N. W. P. (2016). Kemampuan Investigatif Pada Pembuktian Kecurangan Oleh Auditor. E-Jurnal Akuntansi Universitas Udayana, 15, 1029-55.

Dickins, D., \& Reisch, J. T. (2012). Enhancing auditors' ability to identify opportunities to commit fraud: Instructional resource cases. Issues in Accounting Education, 27(4), 1153-1169. https://doi.org/10.2308/iace-50178

Durkin, R. (2011). Forensic auditing: Audit or investigation. National partner in charge of fraud \& misconduct investigations practice. Clifton Gunderson, LLP.

Fullerton, R., \& Durtschi, C. (2004). The effect of professional skepticism on the fraud detection skills of internal auditors. Available at SSRN 617062. https://dx.doi.org/10.2139/ssrn.617062

Gbegi, D. O., \& Adebisi, J. F. (2014). Forensic accounting skills and techniques in fraud investigation in the Nigerian public sector. Mediterranean Journal of Social Sciences, 5(3), 243.

Grabosky, P., \& Duffield, G. (2001). The psychology of fraud. Trends and Issues in Crime and Criminal Justice, 1-6.

Guelpa, A., Marini, F., du Plessis, A., Slabbert, R., \& Manley, M. (2017). Verification of authenticity and fraud detection in South African honey using NIR spectroscopy. Food Control, 73, 1388-1396. https://doi.org/10.1016/j.foodcont.2016.11.002

Hegazy, M. A. E. A., \& Kassem, R. (2010). Fraudulent financial reporting: Do red flags really help. Journal of Economics and Engineering, 4, 69-70.

Heiman-Hoffman, V. B., Morgan, K. P., \& Patton, J. M. (1996). The warning signs of fraudulent financial reporting. Journal of Accountancy, 182(4), 75.

Hussin, S. A. H. S., Iskandar, T. M., Saleh, N. M., \& Jaffar, R. (2017). Professional skepticism and auditors'assessment of misstatement risks: the moderating effect of experience and time budget pressure. Economics \& Sociology, 10(4), 225-250. https://doi.org/10.14254/2071-789X.2017/10-4/17

Jaffar, N., Haron, H., Iskandar, T. M., \& Salleh, A. (2011). Fraud risk assessment and detection of fraud: The moderating effect of personality. International Journal of Business and Management, 6(7), 40. https://doi.org/10.5539/ijbm.v6n7p40

Januarti, I. (2011). Analisis Pengaruh Pengalaman Auditor, Komitmen Profesional, Orientasi Etis dan Nilai Etika Organisasi Terhadap Persepsi dan Pertimbangan Etis (Auditor Badan Pemeriksa Keuangan Indonesia). Paper Dipresentasikan pada Simposium Nasional Akuntansi XIV, Aceh.

Kartikarini, N. (2016). Pengaruh Gender, Keahlian, dan Skeptisisme Profesional terhadap Kemampuan Auditor Mendeteksi Kecurangan (Studi pada Badan Pemeriksa Keuangan Republik Indonesia) (Doctoral dissertation, Universitas Gadjah Mada).

Kassem, R., \& Higson, A. (2012). The new fraud triangle model. Journal of emerging trends in economics and management sciences, 3(3), 191-195. 
Kelley, H. H. (1973). The processes of causal attribution. American psychologist, $28(2)$, 107. https://psycnet.apa.org/doi/10.1037/h0034225

Knapp, C. A., \& Knapp, M. C. (2001). The effects of experience and explicit fraud risk assessment in detecting fraud with analytical procedures. Accounting, Organizations and Society, 26(1), 25-37. https://doi.org/10.1016/S03613682(00)00005-2

Kurniawan, A. (2018). Metodologi Penelitian Pendidikan. Bandung: Rosda Karya.

Kustinah, Siti. 2018. Reds Flag An Effort Against Fraud Detection. Portfolio Journal Vol.15, No, 1. Hal, 15-30. STIESTEMBI-Bandung Business School.

Lameng, A. K. Y. A., \& Dwirandra, A. A. N. B. (2018). Pengaruh Kemampuan, Pengalaman dan Independensi Auditor pada Efektivitas Pelaksanaan Prosedur Audit Investigatif. E-Jurnal Akuntansi, 187-215. https://doi.org/10.24843/EJA.2018.v22.i01.p08

Larasati, D., \& Puspitasari, W. (2019). PENGARUH PENGALAMAN, INDEPENDENSI, SKEPTISISME PROFESIONAL AUDITOR, PENERAPAN ETIKA, DAN BEBAN KERJA TERHADAP KEMAMPUAN AUDITOR DALAM MENDETEKSI KECURANGAN. Jurnal Akuntansi Trisakti, 6(1), 31-42. http://dx.doi.org/10.25105/jat.v6i1.4845

Maulana, P. A. \& Kiswanto K. (2019). MODERASI PENGALAMAN PADA PENGARUH FRAUD RISK ASSESSMENT, SKEPTISME, DAN WORKLOAD TERHADAP KEMAMPUAN MENDETEKSI KECURANGAN. Jurnal Ilmiah Akuntansi dan Bisnis, 183-195. https://doi.org/10.24843/JIAB.2019.v14.i02.p04

Moyes, G. D., Young, R., \& Mohamed Din, H. F. (2013). Malaysian internal and external auditor perceptions of the effectiveness of red flags for detecting fraud. International Journal of Auditing Technology, 1(1), 91-106.

Mui, G. Y. (2010). Factors That Impact On Internal Auditors' Fraud Detection Capabilities-A Report For The Institute Of Internal Auditors Australia. Center for Business Forensics HELP University Malaysia.

Mustika, D., Hastuti, S., \& Heriningsih, S. (2016). Analisis Faktor-faktor yang Mempengaruhi Kecenderungan Kecurangan (Fraud): Persepsi Pegawai Dinas Kabupaten Way Kanan Lampung. Simposium Nasional Akuntansi XIX. Lampung, 1-22.

Nair, P., \& Kamalanabhan, T. J. (2010). Performance pressure and peer reporting of infractions: a moderated mediation model. Journal of Indian Business Research.

Okpianti, C. N. (2016). Pengarruh Pengalaman Auditor, Etika Profesi Dan tipe Kepribadian Terhadap Skeptisisme Profesional Auditor Dan Kemampuan Auditor Dalam Mendeteksi Kecurangan. Universitas Muhammadiyah Yogyakarta Fakultas Ekonomi Dan Bisnis.

Prasetyo, D. A., \& Darmayanti, N. P. A. (2015). Pengaruh Risiko Kredit, Likuiditas, Kecukupan Modal, Dan Efisiensi Operasional Terhadap Profitabilitas Pada PT BPD Bali. E-jurnal Manajemen, 4(9).

Pratama, Nur Azis. Edi Sukarmanto and Pupung Purnamasari. 2019. Effect of Red Flags and Whistleblowing system on the Auditor's Ability to Detect Fraud. Accounting Prosidng. Faculty of Economics and Business, Bandung Islamic University.

Rahmawati, F. (2017). Effect of Competence and Experience of Investigative Auditors on the Effectiveness of Audit Procedure Implementation in Proof of Fraud. E-Journal of UNHAS. Vol. 3 No.1. University of Hasanuddin.

Rumengan, I. P. E., \& Rahayu, S. (2014). Pengaruh Kompetensi, Independensi Dan Pengalaman Kerja Terhadap Kualitas Audit (Survei Terhadap Auditor Kap Di Bandung). Proceedings of Management, 1(3).

Salem, M. S. (2012). An overview of research on auditor's responsibility to detect fraud on financial statements. Journal of Global Business Management, 8(2), 218.

Sanjaya Adi Putra, G., \& Dwirandra, A. A. N. B. (2019). The effect of auditor experience, type of personality and fraud auditing training on auditors ability in fraud detecting with professional skepticism as a mediation variable. International Research Journal of Management, IT and Social Sciences, 6(2), 31-43. https://doi.org/10.21744/irjmis.v6n2.604

Setiawan, L., \& Fitriany, F. (2011). Pengaruh workload dan spesialisasi auditor terhadap kualitas audit dengan kualitas komite audit sebagai variabel pemoderasi. Jurnal Akuntansi dan Keuangan Indonesia, 8(1), 36-53. http://dx.doi.org/10.21002/jaki.2011.03

Suartana, I. W. (2010). Akuntansi Keperilakuan Teori dan Implementasi. Andi. Yogyakarta.

Tuanakotta, T. M. (2012). Forensic Accounting and Investigative Audit. Jakarta's Salemba Empat.

Walgito, B. (2002). Psikologi umum. Yogyakarta: Andi Offset.

Widyastuti, T. (2009). Pengaruh struktur kepemilikan dan kinerja keuangan terhadap manajemen laba: Studi pada perusahaan manufaktur di BEJ. MAKSI, 9.

Narayana, A. A. S., \& Ariyanto, D. (2020). Auditors experience as moderating effect investigative abilities and understanding of red flags on fraud detection. International Research Journal of Management, IT and Social Sciences, 7(1), 205-216. https://doi.org/10.21744/irjmis.v7n1.837 
Wijayanti, T. (2014). Pengaruh kemampuan dan sikap auditor investigatif terhadap efektivitas pelaksanaan prosedur audit dalam pembuktian kecurangan (studi kasus pada auditor investigatif di BPK Provinsi Jawa Timur Surabaya) (Doctoral dissertation, Universitas Negeri Malang).

Yusrianti, H. (2015). Pengaruh Pengalaman Audit, Beban Kerja, Task Specific Knowledge Terhadap Pendeteksian Kecurangan Laporan Keuangan (Studi pada KAP di Sumatera Bagian Selatan). Jurnal Manajemen dan Bisnis Sriwijaya, 13(1), 55-72. https://doi.org/10.29259/jmbs.v13i1.3338

Zimbelman, M. F., Albrecht, C. C., Albrecht, W. S., \& Albrecht, C. O. (2014). Akuntansi Forensik. Jakarta: Salemba Empat. 